\title{
69 TOIMENPIDETTÄ AIKUISKOULUTUKSEN KEHITTÄMISEKSI
}

Viime vuoden marraskuun lopulla valmistui opetusministeriön työryhmän muistio "69 toimenpidettä aikuiskoulutuksen kehittämiseksi'". Työryhmä työskenteli tehokkaasti: aikuiskoulutuksen nykytilan kartoitukseen ja parannusehdotuksiin kului aikaa vajaa viisi kuukautta. Työskentelyä johti ylijohtaja Leevi Melametsä.

Muistioon koottiin toimenpiteet, jotka työryhmän mielestä vaativat kahden lähimmän vuoden aikana kannanottoa, valmistelua tai päätöksentekoa. Toki monet ehdotuksista toteutuvat käytännössä vasta pidemmällä aikavälillä. Seuraavassa on laajasta muistiosta poimittu keskeisimpiä kohtia.

Muistion laatijoita kannusti tietoisuus siitä, että tieto kasvaa ja uusiutuu nopeasti. Nuorena hankitut tiedot ja taidot eivät lo- puttomiin riitä. Teknologian ja tuotannon kehitys muuttavat työtehtäviä ja ammattirakenteita.

Koulutuksen tehtävä ei kuitenkaan ole vain sopeutua yhteiskunnan muutoksiin ja torjua esimerkiksi väestörakenteen muutoksen, ikääntymisen, varhaiseläkkeellepaon yms. haittoja, vaan se on myös keino ohjata yhteiskuntaa ja työelämän kehitystä.

Vaikka aikuiskoulutuksen kehittämisessä on 1980-luvun ajan ammatillinen aikuiskoulutus vahvistanut asemiaan, yksinomaan työvoimakriteerien varaan ei aikuiskoulutusta kokonaisuudessaan - vapaata sivistystyötä vielä vähemmän - tule työryhmän mielestä alistaa. Tämä kannanotto tulee kuitenkin heikohkosti näkyviin konkreettisissa toimenpide-ehdotuksissa. 
Vapaalle sivistystyölle työryhmä näkeekin uusia velvoitteita, sillä juuri se voisi olla riittävän joustava reagoimaan ajan ilmiöihin, kuten nuorten alhainen äänestysaktiivisuus, eläkeläisten määrän kasvu, ympäristökysymykset, kansainvälistymisen aiheuttamat kielitaitovaatimukset, lisääntyvä vapaa-aika ja monikulttuuriset ongelmat.

Koulutuksen kasautuminen on saanut myös huomionsa: motivointikeinoja halutaan arvioitavan lähtökohtana väestöryhmien, elämäntilanteitten ja arvomaailmojen erilaisuus.

\section{Aikuisen opiskelulle olosuhteet otollisiksi}

Edellä kerrotun lisäksi työryhmä esittää tavoitteellisiksi painopisteiksi mm. helpottaa aikuisten osallistumista koulutukseen. Keinona on $\mathrm{mm}$. laajentaa opiskelunaikaista toimeentuloturvaa. Niinpä työryhmä ehdottaa aikuisopintorahakokeilun muuttamista toimeentuloturvajärjestelmäksi, kulukorvausjärjestelmän luontia ja aikuisten tarvitsemien lastenhoitopalvelujen parantamista.

Opintovapaa halutaan joutavammaksi. Se tulisi olla yhdistettävissä vuosilomaan niin haluttaessa. Opetushallinnon toivotaan tukevan sapattivapaan laajentamista ja kokeilua juuri koulutuksellisin perustein.

Eri koulutusmuotoissa suoritetut opinnot, työkokemus ja itseopiskelu halutaan lukea opiskelijan eduksi, kun tutkintoja ja niiden suorittamisperusteita kehitetään. Myös kansainvälistäminen nähdään painopisteenä.

\section{Kysyntä säätelee}

Koulutuspäätökset halutaan kautta linjan kysyntää myötäileviksi. Tämän periaatteen mukaisesti julkiset ja yksityiset työnantajat voisivat ostaa tarvitsemansa koulutuspalvelut niitä tarjoavilta laitoksilta. Näin koulutusjärjestelmä saataisiin palvelemaan korvausta vastaan työnantajien laveaa kenttää, yhtä lailla julkista kuin yksityistäkin sektoria. Koulutuspalvelujen myyjiltä uudistus edellyttäisi omien palveluittensa kehittämistä ja kykyä sopeutua nopeasti muutoksiin. Jähmeä laitos putoaa kilpailusta.

Kysyntää myötäilevä näkemys tulisi kattamaan ammatillisten aikuiskoulutuskeskusten (nykyisten ammatillisten kurssikeskusten) ja korkeakoulujen täydennyskoulutuskeskusten lisäksi iltalukiot, kansanopistot sekä kansalais- ja työväenopistot. Työvoimaviranomaiset ja työnantajat voisivat ostaa koulutusta myös näiltä laitoksilta.

Kysyntä on vallitseva yleissivistävien aikuiskoulutusorganisaatioiden työn säätelijänä. Ihmiset lähtevät mukaan, jos opiskeluaiheet ja -ohjelmat osuvat heidän harrastuksiinsa ja toiveisiinsa.

\section{Henkilökohtaisiin opetusohjelmiin}

Työryhmä korostaa tutkintojen ja niiden vertailtavuuden merkitystä. Pidetään tavoiteltavana, että tutkinnon voi koota monilla eri tahoilla suoritetuista opinnoista ja että suorittamisen muodot ovat joustavat. Tämä edellyttäisi sitä, että aikuisopiskelijalle laaditaan henkilökohtainen opiskeluohjelma, missä mm. työkokemus otetaan huomioon. Opetusmenetelmiä halutaan kehitettävän siten, että aikuisen työ- ja elämänkokemus toimisivat motivoivina elementteinä opiskella. Kansalaisen opintokirjaa pidetään myös käyttökelpoisena ideana. Elinkeinoelämän katsotaan arvostavan, tutkintojen vertailtavuutta, hyvänä esimerkkinä erilaiset kielitutkinnot.

Opetusmenetelmien tulee soveltua aikuisten elämäntilanteisiin joustavasti, esimerkiksi siten, että työ ja opiskelu limittyvät ja opiskelu rakentuu yhä enemmän monimuotoopiskeluun. Monimuoto-opiskelulla tarkoitetaan lähi-, etä- ja itseopiskelun yhdistelmiä, missä hyödynnetään uutta teknologiaa, sekä eri oppilaitosten palveluksien yhdistelmiä.

Eri suunnitteluasteilla tarvitaan myös yhä enemmän tutkittua tietoa siitä, miten esimerkiksi monimuoto-opetus, erilaiset opetusmenetelmät tai opetusohjelmien yhdistelyt toimivat eri elämäntilanteissa ja oppimistilanteissa.

Aikuiskouluttajien kouluttamiseen halutaan myös kasvavasti huomiota: kaikille tällaisissa tehtävissä oleville tulee järjestää täydennyskoulutusta lähimmän kolmen vuoden aikana. Opetusministeriö myös tarkistaa aikuiskoulutuskoulutuksen kehittämissuunnitelmansa.

Opettajien palvelusuhteen ehtoja ja palkkionormeja halutaan joustavammiksi. 
Sähköisten viestimien

\section{suuret mahdollisuudet}

Sähköisesti välitettävä opetus soveltuu erinomaisesti mm. laajojen opiskelijajoukkojen samanaikaiseen opettamiseen, suppean erikoisalan opetukseen opiskelijaryhmien asuessa toisistaan hyvin hajallaan, maantieteellisesti vaikeakulkuisilla alueilla asuvien, vammaisten ja laitoksissa asuvien ihmisten opettamiseen tai yksin opiskeluun.

Kotitalouksien kasvava ja monipuolistuva säihköisten viestimien valikoima lisää mahdollisuuksia uusiin opetusratkaisuihin. Uusina menetelminä ovat Yleisradion rinnalle tulossa ja tulleetkin puhelin-, video- ja satelliittivälitteinen opetus, elektroninen posti ja päätekokoukset. Mahdollisuuksien laajentaminen edellyttää kuitenkin valtion ja Yleisradion yhteistä toimintaohjelmaa, jossa sovitaan ohjelmien tuotannosta, jakelusta, rahoituksesta, tekijänoikeuksista, oppimateriaalien laadinnasta jne.

Tarvitaan kokeiluja, tutkimustyötä ja jatkuvaa kehittelyä.

\section{Vapaata sivistystyötä koskevia hankkeita}

Sekä aikuislukioiksi nimeltään muuttuvia iltalukioita, kansanopistoja ja kansalais- ja työväenopistoja koskeva lainsäädäntö luvataan uudistaa siten, että kaikille näille oppilaitoksille tulee oikeus myydä koulutuspalveluitaan esimerkiksi työnantajille ja työvoimahallinnolle.

Aikuislukioiden sekä kansalais- ja työväenopistojen mahdollinen paikkakuntakohtainen päällekkäisyys selvitetään ja samalla pohditaan mahdollisuuksia yhdistää niiden toiminnot tai uusia työnjakoa. Samalla selvitetään, tulisiko kansalais- ja työväenopistoille antaa lukion todistuksenanto-oikeus.

Ylioppilastutkintoasetusta aiotaan muuttaa mm. siten, että yli 25-vuotias aikuisopiskelija voi suorittaa tutkinnon useamman vuoden aikana.

Kansanopistojen kurssien pituuksiin ja valtionapuperusteisiin ehdotetaan muutoksia. Uutta olisi myös se, että opistot voisivat toimia kokeiluluonteisesti pelkästään kurssikeskuksina.
Kansalais- ja työväenopistojen ryhmäkokosäännöksistä aiotaan luopua, samoin henkilöstörajoituksista. Opistoille tulisi mahdollisuus etäopetuksen järjestämiseen sekä erilaiseen kokeilu- ja kehittämistoimintaan.

Opintokeskuksille työryhmä lupaa uutta kitsaimmin: alueverkostoa aiotaan vahvistaa viiden seuraavan vuoden aikana sekä "'ottaa opintokeskuslainsäädäntöä uudistettaessa huomioon toiminnan erityispiirteet".

Kesäyliopistojen toiminnan päämuodot ovat 1) avoin korkeakouluopetus, 2) ammattillinen täydennyskoulutus ja 3) yleissivistävä koulutus. Työryhmä ehdottaa kesäyliopistojen valtionapua koskevan valtioneuvoston päätöksen kumoamista ja korvaamista uudella ministeriön päätöksellä. Siinä kesäyliopistot saisivat yleisavustuksena harkinnanvaraista avustusta sekä lähinnä avoimen korkeakouluopetuksen avustusta. Hallinnollisesti kesäyliopistot siirrettäisiin muun yleissivistävän aikuiskoulutuksen yhteyteen.

\section{Rahaa ja resursseja kokeiluun ja tutkimukseen}

Työryhmä ehdottaa, että valtion tulo- ja menoarviossa osoitettaisiin oma momentti yleissivistävän aikuiskoulutuksen kokeilu-, tutkimus- ja kehittämistoimintaan sekä oppimateriaalien valmistukseen.

\section{Ammatillinen aikuiskoulutus}

Aikuisten omaehtoisen ammatillisen peruskoulutuksen oppilasmäärä aiotaan kolminkertaistaa nykyisestä 6 500:sta viidessä vuodessa. Painopiste on erityisesti aloilla, joissa on työvoimapulaa ja alhainen koulutustaso. Myös yksityisopiskelijain määrä nousee lähes kolminkertaiseksi eli 5500 henkeen. Myös henkilöstökoulutuksen halutaan laajenevan ammatillisen peruskoulutuksen puolelle. Ohjaus ja tukitoiminta halutaan mahdollisimman yksilökeskeiseksi.

Ammatilliset jatkokoulutuspaikat lisääntyvät 3 500:sta 7 800:an samana aikana. Ammatilliselle puolelle on myös luvassa omaehtoisen kurssitoiminnan laajentumista sekä lisää virkoja. Työpaikkakoulutusta koskeva lainsäädäntö uudistetaan. Pätevyystutkintoja ajanmukaistetaan ja laajennetaan uusille 
aloille. Mahdollisuuksia valmentautua tutkintoihin lisätään mm. kurssimuotoisella lisäkoulutuksella.

Ammatilliseen koulutukseen suunnataan varoja oppilaitoksissa toimeenpantavia kokeiluja ja tutkimustoimintaa varten. Kokeilujen ja tutkimuksen toivotaan suuntautuvan opetusmenetelmiin, opetusjärjestelyihin, erityisesti monimuoto-opetukseen, arvioinnin ja osaamisen mittausmenetelmiin, opettajien työhön sekä elinkeinoelämän ja oppilaitosten keskinäisen yhteistyön kehittämiseen.

\section{Kuluttajaneuvonta}

Kuluttajaneuvonnan ja kotitalouksien taloudellisen neuvonnan tarve kasvaa voimakkaasti lähivuosina. Ammattikasvatushallituksessa on valmistunut selvitys neuvontatoiminnan valtionapuperusteiden korjaamisesta sekä neuvonnan ja koulutuksen päällekkäisyyksien karsimisesta.
Nykyisin valtioapua saa 28 neuvonta- ja kuluttajavalistusjärjestöä.

\section{Korkeakoulujen täydennyskoulutus}

Työryhmä pitää korkeakoulujen täydennyskoulutuksen valikoimaa yksipuolisena. Niinpä koulutusta ei ole riittävästi sellaisilla kasvavilla yhteiskunnan alueilla, kuten kansainvälistyminen, biotekniikka, ympäristönsuojelu tai tietotekniikka. Keinona uusiin suuntaamisiin pidetään $\mathrm{mm}$. riskirahaa ja sen suuntaamista.

Avoimelle korkeakouluopetukselle laaditaan yhtenäiset valintaperusteet, joissa otetaan huomioon avoimen korkeakoulun luonne kaikille avoimena koulutusväylänä.

Aikuiskoulutuksen johtoryhmä seuraa 69 toimenpide-ehdotuksen etenemistä ja tarkistaa toteutumisohjelman kuluvan vuoden lopussa. - AK 